\title{
PHENOLIC COMPOUNDS OF SERRATULA CENTAUROIDES AND ANXIOLYTIC EFFECT
}

\author{
SERGEI MATVEEVICH NIKOLAEV ${ }^{1,3}$, IRINA GENNADYEVNA NIKOLAEVA ${ }^{1,2 *}$, YANINA \\ GENNADYEVNA RAZUVAEVA ${ }^{1,2}$, IRINCHEI EDUARDOVICH MATKHANOV ${ }^{1}$, LILIYA \\ PURBUEVNA TSYBIKTAROVA ${ }^{2}$, LARISA NIKOLAEVNA SHANTANOVA ${ }^{1,2}$, GALINA \\ GRIGORYEVNA NIKOLAEVA ${ }^{1,2}$
}

${ }^{I}$ Institute of General and Experimental Biology SB RAS (IGEB SB RAS), 6 Sakhynovoi Street, 670047, Ulan-Ude, Russia ${ }^{2}$ Buryat State University (BSU), 24 a Smolina Street, Ulan-Ude, Russia

${ }^{3}$ Irkutsk State Medical Academy of Postgraduate Education - Branch Campus of the Russian Medical Academy of Continuing Professional Education, 100 Yubilejnyj, Irkutsk, Russia

*corresponding author: i-nik@mail.ru

Manuscript received: July 2018

\begin{abstract}
The paper presents the results of the study of a dry extract of Serratula centauroides (Asteraceae) using a HPLC method and estimation of his anxiolytic activity. 17 phenolic substances and 15 respectively were identified in the herb in the roots. In the herb of the plant, there were revealed hyperoside and luteolin. The aerial part contains twice as much ecdysterone as the roots of $S$. centauroides. The experiments conducted on animals have shown that the $S$. centauroides dry extract at the doses comprised between $50-150 \mathrm{mg} / \mathrm{kg}$ bw has a marked anxiolytic effect. $S$. centauroides extract increases the number of entries into the open branches of elevated plus maze (EPM) and prolongs a residence time in the open arms of EPM and light compartment of the dark/light chamber. The use of $S$. centauroides increases the number of punished water intakes in the Vogel conflict test.
\end{abstract}

\section{Rezumat}

Lucrarea prezintă rezultatele studiului efectuat asupra extractului uscat obținut de la Serratula centauroides (Asteraceae) prin metoda HPLC și estimarea activitătii anxiolitice a acestuia. Au fost identificate 17 substanțe fenolice în partea aeriană a plantei și 15 substanțe fenolice în rădăcini. În partea aeriană a plantei au fost descoperite hiperozida și luteolina. Partea aeriană conține de două ori mai mult ecdysteron decât rădăcinile de $S$. centauroides. Experimentele pe animale au arătat că extractul uscat administrat în doze cuprinse între $50-150 \mathrm{mg} / \mathrm{kgc}$ are un efect anxiolitic marcant în testul labirintului și testul Vogel.

Keywords: Serratula centauroides (L.), phenolic compounds, HPLC, anxiolytic effect

\section{Introduction}

Serratula centauroides (L.) of Asteraceae family is an ecdysteroid-containing plant commonly found in Siberia, Far East, Mongolia, Europe and Caucasus $[8,15]$. The plant material contains a complex of following biologically active substances: ecdysteroids, flavonoids, polysaccharides, tannins, triterpenoid saponins, coumarins and amino acids [11]. The lipid composition of the plant has been studied and fat acids, phytosterols, alkanes and hydroxy acids have been identified [22]. The ether oil component composition of the plant has been determined [23]. In the plant material of $S$. centauroides there were identified B vitamins [21]. Among ecdysteroids there were identified 20-hydroxyecdysone (ecdysterone), 2-desoxy-20hydroxyecdisone, integristerone A and viticosterone $\mathrm{E}$. in the underground and aerial organs of Serratula centauroides there was studied the distribution of 20hydroxyecdysone (ecdysterone), 2-desoxy-20-hydroxyecdisone and integristerone [26, 27]. The presence of 20-hydroxyecdysone (ecdysterone) and 2-desoxy20-hydroxyecdisone is characteristic for most species of Serratula [1, 25]. 20-hydroxyecdysone is prevalent among ecdysteroids extracted from the plant; the total content of ecdysteroids in the herb of $S$. centauroides amounts to $1.42 \%$ [12].

In the folk medicine, particularly, in the practice of Buryat lamas, the decoction of the plant was used as antihaemorrhagic remedy [3]; the experiments have revealed that preparations from the plant have haemostatic and anabolic properties [15].

The dry extract from the $S$. centauroides herb has shown nootropic, antihypoxic, anticonvulsant and membrane stabilizing effects in the conducted studies [17-19].

The present research aimed the study of phenolic composition of Serratula centauroides by HPLC method and estimation of the anxiolytic activity of the dry extract obtained from $S$. centauroides. 
FARMACIA, 2019, Vol. 67, 3

\section{Materials and Methods}

The specimens of the Serratula centauroides aerial part were gathered in Ivolginsky district of Buryatia Republic (Russia) in July 2017 in the flowering period and roots were gathered in August 2017 in the wilting period.

The study of the phenolic composition in the aerial part and roots of $S$. centauroides was carried out on a HPLC ("Gilson", France), manual injector (Rheodyne 7125 , USA) with the following computer processing of the results (Multichrom program for Windows). As a stationary phase there was used a metal column (4.6 x $250 \mathrm{~mm}$ ) filled with Chromasil C18; the size of the particles -5 microns. As a mobile phase there was used methanol-water-concentrated phosphoric acid (400:600:5). The analysis was carried out at room temperature. The rate of eluent feed was $0.8 \mathrm{~mL} / \mathrm{min}$. The duration of the analysis was $170 \mathrm{~min}$. Detection was carried out with the use of an UV-detector ("Gilson" UV/VIS, 151) at $254 \mathrm{~nm}$ wave length. The following reliable samples of compounds were used for the identification of substances in the extracts: rutin (Sigma Aldrich, USA, cat. No R5143; $\geq 94 \%$ ), quercetin (Sigma Aldrich, USA, cat. No Q4951; $\geq$ 95\%), luteolin (Sigma Aldrich, USA, cat. No L9283; $\geq 98 \%$ ), gallic acid (Sigma Aldrich, USA, cat. No G7384; $\geq 97.5 \%$ ), caffeic acid (SigmaAldrich, USA, cat. No C0625; $\geq 98 \%$ ), chlorogenic acid (Sigma Aldrich, USA, cat. No C3878; $\geq 95 \%$ ), hyperoside (Sigma Aldrich, USA, cat. No 83388; $\geq 97 \%$ ), ferulic acid (Sigma Aldrich, USA, cat. No128708; $\geq 99 \%$ ), neochlorogenic acid (SigmaAldrich, USA, cat. No 94419; $\geq 98 \%$ ), chicoric acid (SigmaAldrich, USA, cat. No C7243; $\geq 95 \%$ ), dicoumarin (Sigma Aldrich, USA, cat. No M1390; $\geq 94 \%$ ), dihydroquercetin (Sigma Aldrich, USA, cat. No T4512; $\geq 90 \%$ ), epicatechin (Sigma Aldrich, USA, cat. No E1753; $\geq$ 90\%), ecdysterone (Sigma Aldrich, USA, cat. No H5142; $\geq 93 \%$ ), o-methoxycoumarin (Sigma Aldrich, USA, cat. No W515809; $\geq 98 \%$ ) and epigallocatechin gallate (Sigma Aldrich, USA, cat. No E4143; $\geq 95 \%$ ). Identification of separated substances was carried out by comparing retention times of peaks in the chromatogram of the tested solution with those in the standard solution chromatogram. The quantitative ratio of identified substances in the tested samples was estimated according to the peaks square with the use of the internal normalization method.

The plant material was ground up till particles passing through cover with $2 \mathrm{~mm}$ sieve size. Precise test portion $(\approx 2.0 \mathrm{~g})$ of the comminuted plant material was put into the retort $(\mathrm{V}=100 \mathrm{~mL})$ and $20 \mathrm{~mL}$ of $70 \%$ ethyl alcohol was added; the retort was connected to a backflow condenser and heated on a water bath for 1 hour since boiling of the alcohol mixture. After cooling the mixture was filtered through a paper filter into the measuring bottle $(\mathrm{V}=$
$25 \mathrm{~mL}$ ) and then ethyl alcohol was added till mark (solution A). At the same time the series of $0.05 \%$ solutions of comparison, namely, the solutions of rutin, quercetin, luteolin, gallic acid, caffeic acid, chlorogenic acid, hyperoside, ferulic acid, neochlorogenic acid, chicoric acid, dicoumarin, dihydroquercetin, epicatechin, ecdysterone, omethoxycoumarin and epigallocatechin gallate were prepared in $70 \%$ ethyl alcohol. The tested solutions and the solutions of comparison in the volume of $50 \mu \mathrm{L}$ each were put into the chromatograph and were chromatographed according to the above method.

To obtain the dry extract from $S$. centauroides the comminuted herb (the plant material was gathered in July 2017) was triply extracted with 70, 40 and $20 \%$ ethyl alcohol successively at a temperature of $60^{\circ} \mathrm{C}$. Alcoholic extractions were boiled off and dried in the vacuum oven. The dry extract was the amorphous hydroscopic brown powder with specific odour; weight loss on drying is not more than 5\%.

The pharmacological studies were carried out on 144 white male and female Wistar rats weighing 180 - $200 \mathrm{~g}$. They were maintained in standard laboratory conditions of the vivarium at the Institute of General and Experimental Biology SB RAS. 10 rats were housed per plastic cage on wood shavings litter. The temperature in the vivarium was $20-22^{\circ} \mathrm{C}$, indoor air humidity was not more than $50 \%$, air exchange (air intake/outlet) was 8:10, light regime (day/night) was 1:1. The animals were fed twice a day. The animal care was compliant with the "Rules of Laboratory Practice" (GLP) and the Order of the Russian Health Ministry "On approval of Rules for Laboratory Practice” (No. 708N, 23.08.2010).

The experimental work followed the European Communities Council Directive of 24 November 1986 (86/609/EEC). The research report was approved by the Ethics Committee at IGEB SB RAS (Protocol $\mathrm{N} 1$ dated 28.01.2014). The Ethics Committee protocol is valid till the project finish (2020).

Before the start of the experiments, the animals meeting the criteria (apparently healthy, mature, aged $10-11$ months) were divided into groups with due account of sex, age, weight and randomization principle.

The dry extract from $S$ centauroides was administered to animals of experimental groups at the doses of 50, 100 and $150 \mathrm{mg} / \mathrm{kgbw}$ in the form of water solution for 7 days before study; the last dose was administered 1 hour before testing. The animals of the control group received the purified water in the equivalent volume according to the analogous scheme. Each group consisted of 36 animals. 12 animals from each group were used for one test.

Anxiolytic effect of $S$. centauroides was estimated according to methodical guidelines for the study of tranquilizing (anxiolytic) effect of pharmacological substances [28]. 
In the elevated plus maze (EPM) test there was used a device consisting of two open $(10 \mathrm{~cm} \times 10 \mathrm{~cm} \times$ $50 \mathrm{~cm})$ and two enclosed arms $(10 \mathrm{~cm} \times 10 \mathrm{~cm} \times 50$ $\mathrm{cm})$, extending from a central platform at right angle to the centre $(5 \mathrm{~cm} \times 5 \mathrm{~cm})$ and raised $80 \mathrm{~cm}$ above floor level. The given test was based on the natural preference of rats for dark areas and aversion for open and elevated areas. Just before the beginning of the experiment the animals stayed in dark cages for 3 minutes. Then the animals were placed in the centre of the maze, facing an open arm. The time spent in the open and closed arms, the number of entries into the open and closed arms, rearings and defecations were recorded during a 5 min observation period.

The light/dark test was also based on the natural aversion of rodents to brightly illuminated areas. In the given experiment, the animals were placed in the light compartment and the number of transfers from the dark compartment to the light compartment and the time spent in the light and dark compartments were recorded over $5 \mathrm{~min}$.

A conflict situation according to the Vogel test was created colliding water-intake and self-defence motivations. In this test the rats were water-deprived for $48 \mathrm{~h}$ without limiting feed; on the $3^{\text {rd }}$ day the rat was housed in the chamber with a waterer. After habituation to drinking from the waterer on the $4^{\text {th }}$ day the rat was housed in the chamber for 3 minutes and every 10 seconds each water intake was punished by a mild electric shock ( $1 \mathrm{~mA})$. As a result, to satisfy thirst the rat had to get over fear of punishment. The anxiolytic effect of the $S$. centauroides extract was estimated according to the number of punished water intake during a three min observation period.

Experimental material was processed with the use of statistic programs Microsoft Excel 2010 and Statistica 13. The data were expressed as means $(M) \pm$ S.E.M (m). Validity of differences in means between groups was estimated with the use of the Student's t-test (for independent groups the differences were considered significant when $\mathrm{p}<0.05$ ).

\section{Results and Discussion}

The studies revealed 25 compounds, 17 of them are of phenolic nature (Table I, Figure 1). The data in the Table I have shown that the quantitative composition and qualitative content of substances in specimens have some differences: 17 substances were identified in the aerial part and 15 ones - in the roots of $S$. cenrauroides. Among identified substances, flavonoids prevail in the aerial part topping $31.28 \%$ of the total quantity of identified substances and phenol carbonic acids prevail in the roots $(36.12 \%)$. The content of phenol carbonic acids in the aerial part is $24.52 \%$ and the content of flavonoids in the roots is $30.40 \%$ of the total quantity of the identified substances. The content of coumarins in the aerial part and roots of $S$. centauroides is roughly equal, 22.90 and $21.08 \%$ respectively. In the aerial part of the plant unlike the roots there were revealed hyperoside and luteolin. The content of ecdysterone in the aerial part $(21.30 \%)$ is twice its content in the roots $(12.40 \%)$.

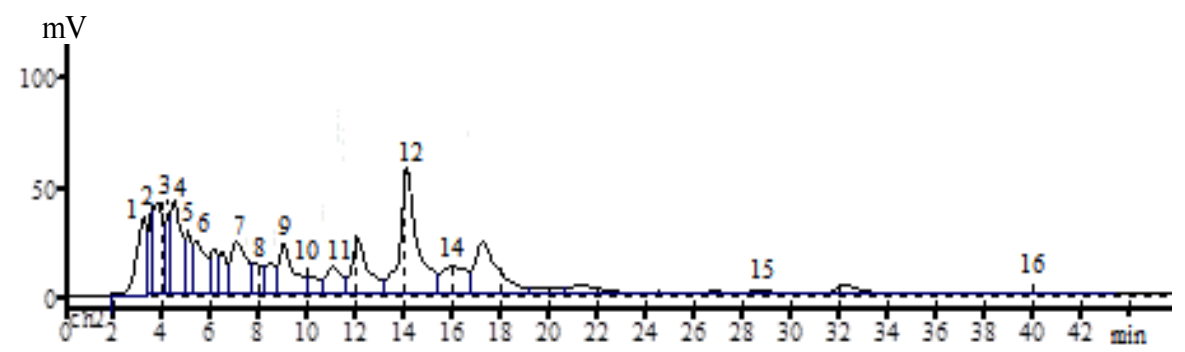

a

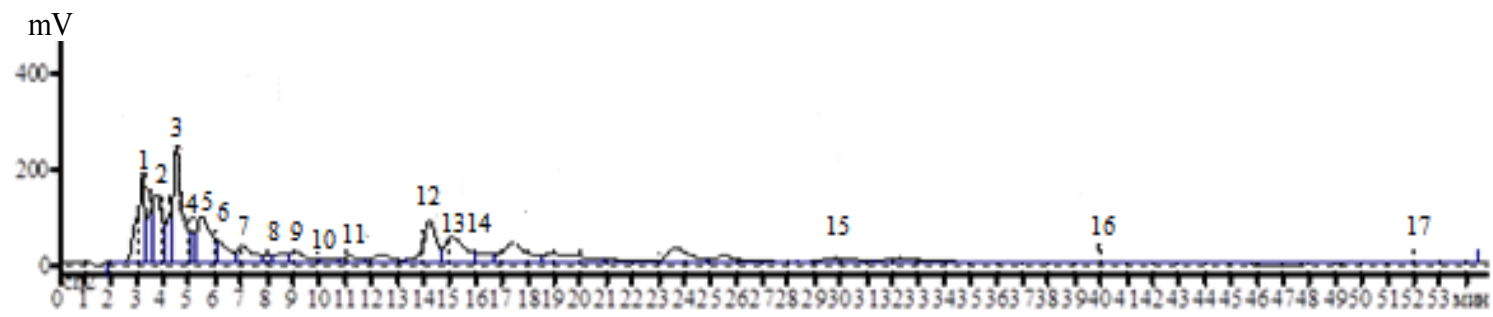

b

Figure 1.

(a) Chromatogram of extractions from $S$. centauroides roots; (b) Chromatogram of extractions from $S$. centauroides aerial part 
Phenolic composition of $S$. centauroides

\begin{tabular}{|c|l|c|c|c|}
\hline \multirow{2}{*}{ Name } & Retention time, & \multicolumn{2}{c|}{ Aerial part } & Roots \\
\cline { 3 - 4 } & & $\min$ & The content, \%, method of internal normalization \\
\hline 1 & Gallic acid & 3.66 & 7.34 & 5.62 \\
\hline 2 & Epigallocatechin gallate & 4.20 & 2.51 & 2.11 \\
\hline 3 & Dicoumarin & 4.46 & 11.11 & 6.71 \\
\hline 4 & Chlorogenic acid & 5.05 & 1.81 & 2.40 \\
\hline 5 & Epicatechin & 5.43 & 7.43 & 4.20 \\
\hline 6 & Caffeic acid & 6.08 & 2.78 & 2.26 \\
\hline 7 & Chicoric acid & 6.97 & 3.26 & 5.43 \\
\hline 8 & Neochlorogenic acid & 7.84 & 0.80 & 2.28 \\
\hline 9 & Dihydroquercetin & 9.04 & 2.50 & 5.04 \\
\hline 10 & Ferulic acid & 10.37 & 0.96 & 1.81 \\
\hline 11 & Coumarin & 11.11 & 1.52 & 2.96 \\
\hline 12 & Ecdysterone & 14.18 & 14.73 & 6.80 \\
\hline 13 & Hyperoside & 15.05 & 5.84 & - \\
\hline 14 & Rutin & 16.03 & 2.15 & 4.41 \\
\hline 15 & O-methoxycoumarin & 29.76 & 3.20 & 1.89 \\
\hline 16 & Quercetin & 39.85 & 0.99 & 0.91 \\
\hline 17 & Luteolin & 52.43 & 0.21 & - \\
\hline
\end{tabular}

The results of pharmacological studies have shown that the course administration of the $S$. centauroides extract using doses of 50, 100 and $150 \mathrm{mg} / \mathrm{kgbw}$ relieved anxiety and fear increasing the punished water intake by $1.7,2.3$ and 1.8 times respectively as compared to the control group (Table II).

Table II

Influence of the dry extract from $S$. centauroides on the behaviour of white rats in the elevated plus maze (EPM) test

\begin{tabular}{|c|c|c|c|c|}
\hline \multirow[b]{2}{*}{ Indices } & \multicolumn{4}{|c|}{ Animal groups } \\
\hline & $\begin{array}{c}\text { Control } \\
\left(\mathrm{H}_{2} \mathrm{O}\right)\end{array}$ & $\begin{array}{c}\text { Experimental } 1 \\
\text { (extract of } S . \text { centauroides, } \\
50 \mathrm{mg} / \mathrm{kgbw} \text { ) }\end{array}$ & \begin{tabular}{|c} 
Experimental 2 \\
(extract of $S$. centauroidis, \\
$100 \mathrm{mg} / \mathrm{kgbw}$ )
\end{tabular} & $\begin{array}{c}\text { Experimental } 3 \\
\text { (extract of } S . \text { centauroidis, } \\
150 \mathrm{mg} / \mathrm{kgbw} \text { ) }\end{array}$ \\
\hline \multicolumn{5}{|c|}{ Number of entries } \\
\hline Open arm & $0.6 \pm 0.2$ & $1.1 \pm 0.4$ & $0.9 \pm 0.3$ & $0.8 \pm 0.2$ \\
\hline Closed arm & $1.8 \pm 0.2$ & $2.5 \pm 0.4$ & $2.9 \pm 0.3^{*}$ & $2.1 \pm 0.3$ \\
\hline \multicolumn{5}{|c|}{ Residence time } \\
\hline Open arm & $4.4 \pm 1.6$ & $13.5 \pm 6.9$ & $10.8 \pm 3.6$ & $9.3 \pm 6.4$ \\
\hline Closed arm & $289.2 \pm 2.6$ & $274.9 \pm 10.8$ & $277.0 \pm 5.2$ & $279.3 \pm 0.4$ \\
\hline Central area & $6.4 \pm 1.0$ & $11.4 \pm 4.2$ & $13.0 \pm 3.9$ & $11.4 \pm 4.8$ \\
\hline Rearing & $3.9 \pm 0.4^{*}$ & $9.8 \pm 1.3$ & $11.0 \pm 1.4^{*}$ & $6.4 \pm 0.9^{*}$ \\
\hline Defecation & $1.5 \pm 0.1^{*}$ & $0.6 \pm 0.2$ & $0.4 \pm 0.1^{*}$ & $0.5 \pm 0.2^{*}$ \\
\hline
\end{tabular}

$*$ - $\mathrm{p} \leq 0.05 v s$. control

The testing of animals in the light/dark compartment and EPM has shown that the control animals preferably spent time in the dark compartment and closed arms of EPM (Table II, Table III).

The use of the $S$ centauroides extract relieved fear of the open area in the EPM (Table III). In the first and second experimental groups, the number of entries into the open arms was 1.8 and 1.6 times increased, the time spent in them was 3.1 and 2.5 times increased and the time spent in the central area was 1.8 and 2.0 times increased respectively as compared to the same indices in the control group animals. The extract of $S$. centauroides at the dose of $150 \mathrm{mg} / \mathrm{kgbw}$ demonstrated less pronounced influence in the given indices.
Besides, more active locomotion expressed by an increased number of closed arm entries and rearing was noted in all experimental groups in the EPM as compared to the control animals (Table III). The increase in the exploration activity and reduced fear and anxiety in animals of the experimental groups may be explained by emotional intensity decrease. In animals of the experimental groups the number of faecal boluses was 3.0 times lower than in the control animals.

The course administration of the $S$. centauroides to animals at the doses of 50 and $150 \mathrm{mg} / \mathrm{kgbw}$ increases the number of transitions between dark and light compartments by $48 \%$ and the residence time in the light compartment - by $49 \%$ and $30 \%$ as compared to these indices in control group animals (Table II). In 
the given experiment, the $S$. centauroides extract at the dose of $100 \mathrm{mg} / \mathrm{kgbw}$ has more marked anxiolytic effect increasing the given indices by $76 \%$ and $52 \%$ as compared to the control.

The administration of the $S$. centauroides extract at the doses of 50, 100 and $150 \mathrm{mg} / \mathrm{kgbw}$ increased the number of punished water-intakes in the Vogel test by $2.9,3.2$ and 3.9 times respectively as compared to the control group (Table III).

Table III

The influence of the dry extract from $S$. centauroides on the behaviour of rats in the "dark/light" test and Vogel conflict test

\begin{tabular}{|l|c|c|c|}
\hline \multicolumn{1}{|c|}{ Animal groups } & $\begin{array}{c}\text { Number of transfers } \\
\text { in the dark/light } \\
\text { chamber }\end{array}$ & $\begin{array}{c}\text { Residence time } \\
\text { in the light } \\
\text { compartment }\end{array}$ & $\begin{array}{c}\text { Number of } \\
\text { punished } \\
\text { water-intakes }\end{array}$ \\
\hline Control $\left(\mathrm{H}_{2} \mathrm{O}\right.$ ) & $2.9 \pm 0.3$ & $40.1 \pm 4.9$ & $1.8 \pm 0.3$ \\
\hline Experimental 1 (extract of $S$. centauroidis, $50 \mathrm{mg} / \mathrm{kgbw}$ ) & $4.3 \pm 0.6^{*}$ & $59.9 \pm 5.2^{*}$ & $5.3 \pm 0.8^{*}$ \\
\hline Experimental 2 (extract of $S$. centauroidis, $100 \mathrm{mg} / \mathrm{kgbw})$ & $5.1 \pm 0.5^{*}$ & $60.8 \pm 5.2^{*}$ & $5.8 \pm 0.6^{*}$ \\
\hline Experimental 3 (extract of $S$. centauroidis, $150 \mathrm{mg} / \mathrm{kgbw}$ ) & $4.3 \pm 0.6^{*}$ & $52.3 \pm 5.0$ & $7.0 \pm 1.3^{*}$ \\
\hline
\end{tabular}

Psychic disorders are known to be common. Both synthetic and plant remedies are widely used for the treatment of anxio-depressive disorders. Studies conducted in animals have shown that the anxiolytic effect of plant remedies is due to the complex of bioactive substances such as terpenes, flavonoids, phenolic acids, lignans, cinnamates and saponins.

Numerous structurally different classes of phytochemicals demonstrate high affinity for the benzodiazepine binding site of the GABA-A receptor complex. Specific plant-derived ligands (such as alkaloids, terpenes, flavonoids, phenolic acids, lignans, cinnamates, or saponins) were described to modulate the GABA-A receptor. These compounds cause membrane hyperpolarization by allowing chloride anion $\mathrm{Cl}^{-}$influx, which is followed by inhibition of excitatory transmission and reduction of anxiety [2, 6, 9, 24].

Accumulating evidence showed that the consumption of flavonoid-rich foods is associated with lower rates of dementia and has some beneficial effects on memory and learning [29]. Phenolic hydroxyl groups of flavonoids contribute to their antioxidant, antiradical and anti-inflammatory properties. According to Wang X et al. the phenolic group provides anxiolytic properties of compounds. The anxiolytic activities of seven simple phenols, including phloroglucinol, eugenol, protocatechuic aldehyde, vanillin, thymol, ferulic acid and caffeic acid were assayed with the elevated plus maze (EPM) test in mice [30]. Quercetin reportedly also has anxiolytic properties. The course administration of quercetin to white rats at the dose of $20 \mathrm{mg} / \mathrm{kgbw}$ significantly increased the number of entries in the open arms of the plus-maze and prolonged the time spent there, without a significant change in the locomotor activity of animals [7].

Quercetin and rutin isolated from Tagetes erecta L. have demonstrated anxiolytic properties [14]. Coleta M et al. have reported that $5 \mathrm{mg} / \mathrm{kgbw}$ luteolin increases the percentage of entries into the open arms of the EPM influencing no time spent in those areas [5].
Bouayed et al. revealed anxiolytic effect of chlorogenic acid with the use of the EPM and "light/dark box" tests [4]. Chlorogenic acid has neuroprotective effect in vitro and in vivo conditions [16]. Rosmarinic acid and its metabolite - caffeic acid isolated from the Perilla herb have a marked anxiolytic and antidepressant properties [20]. Chemically pure caffeic acid, at the dose of $1 \mathrm{mg} / \mathrm{kgbw}$ increases the number of entries and time spent in the open arms of the EPM and at the doses of $0.5-2 \mathrm{mg} / \mathrm{kgbw}$ it influences the locomotor and exploratory activities of the animals in the open-field test [13]. Gallic acid demonstrates the properties of classic anxiolytic at the doses comprised between 50 - $300 \mathrm{mg} / \mathrm{kgbw}$ (single administration) [10], and at the dose of $20 \mathrm{mg} / \mathrm{kgbw}$ (long-term administration) [7].

\section{Conclusions}

Thus, the phenolic composition of the aerial part and roots of Serratula centauroides (Asteraceae) has been studied. There have been identified 17 substances of phenolic nature including flavonoids, phenol carbonic acids, coumarins, etc. In the aerial part, unlike the roots, there have been found hyperoside and luteolin. The ecdysterone content in the aerial part is twice as large as in the roots. The wealth of biologically active substances in the aerial part of $S$. centauroides contributes to the marked anxiolytic effect of the tested extract.

The $S$. centauroides extract at the doses comprised between 50 and $150 \mathrm{mg} / \mathrm{kgbw}$ has the marked anxiolytic effect in the conditions of punished behaviour, significantly increasing the number of punished water-intake in the Vogel conflict test and unpunished behaviour increasing the number of entries and time spent in open arms of the EPM and the number of transitions and time spent in the light compartment of the dark/light box. 


\section{Acknowledgement}

The authors acknowledge the financial support provided by the Federal Agency for Scientific Organizations (FASO Russia), Project No AAAA-A17117011810037.

\section{Conflict of interests}

Authors declare no conflict of interests.

\section{References}

1. Abubakirov NK, Ecdysteroids of flowering plants (Angiospermae). Chem Natur Comp., 1981; 6: 489-503.

2. Adachi N, Tomonaga S, Tachibana T, Denbow DM, Furuse M, (-)-Epigallocatechin gallate attenuates acute stress responses through GABAergic system in the brain. Eur J Pharmacol., 2006; 531(1-3): 171-175.

3. Aseeva TA, Dashiev DB, Dashiev AD, Nikolaev SM, Surkova NA, Chekhirova GV, Yurina TA, Tibetan medicine at the Buryats. Novosibirsk, 2008; 324, (available in Russian).

4. Bouayed J, Rammal H, Dicko A, Younos C, Soulimani R, Chlorogenic acid a polyphenol from Prunus domestica (Mirabelle), with coupled anxiolytic and antioxidant effects. J Neurol Sci, 2007; 262: 77-84.

5. Coleta M, Campos MG, Cotrim MD, de Lima TCM, da Cunha AP, Assessment of luteolin $\left(3^{\prime}, 4^{\prime}, 5,7-\right.$ tetrahydroxyflavone) neuropharmacological activity. Behav Brain Res., 2008; 189(1): 75-82.

6. Fedotova J, Kubatka P, Büsselberg D, Shleikin AG, Caprnda M, Dragasek J, Rodrigo L, Pohanka M, Gasparova I, Nosal V, Opatrilova R, Qaradakhi T, Zulli A, Kruzliak P, Therapeutical strategies for anxiety and anxiety-like disorders using plant-derived natural compounds and plant extracts. Biomed Pharmacother., 2017; 95: 437-446.

7. Georgieva A, Belcheva I, Belcheva S, Tashev R, Valcheva-Kuzmanova S, Anxiolytic-like effect of gallic acid and quercetin in young/healthy rats. Eur Neuropsychopharmacol., 2016; 26(2): 270-S271.

8. Grubov VI, Manual for the identification of the vascular plants of Mongolia (with atlas) - Mongolyn tsorgot Urgamal tanih bichig (Zurgiyn hamtaar). Leningrad; Nauka: 1982, (available in Russian).

9. Hernandez-Leon A, González-Trujano ME, FernándezGuasti A, The anxiolytic-like effect of rutin in rats involves GABAA receptors in the basolateral amygdale. Behav Pharmacol., 2017; 28(4): 303-312.

10. Mansouri MT, Soltani M, Naghizadeh B, Farbood Y, Mashak A, Sarkaki A, A possible mechanism for the anxiolytic-like effect of gallic acid in the rat elevated plus maze. Pharmacol Biochem Behav., 2014; 117: 40-46.

11. Nikolaeva GG, Shantanova LN, Nikolaeva IG, Radnaeva LD, Garmaeva LL, Tsybiktarova LP, Rhaponticum uniflorum L. and Serratula centauroides L. are promising ecdysteroid-containing plants. Bulletin ESSC SB RAS, 2014; 3(97): 91-96, (available in Russian).

12. Nikolaeva IG, Tsybiktarova LP, Garmaeva LL, Nikolaeva GG, Olennikov DN, Matkhanov IE,
Determination of ecdysteroids in Fornicium uniflorum (L.) and Serratula centauroides (L.) raw materials by chromatography-UV-spectrophotometry. J Anal Chem., 2017; 8: 854-861.

13. Pereira P, Oliveira PA, Ardenghi P, Rotta L, Henriques JA, Picada JN, Neuropharmacological analysis of caffeic acid in rats. Basic Clin Pharmacol Toxicol., 2006; 99: 374-378.

14. Pérez-Ortega G, Angeles-López GE, Argueta-Villamar A, González-Trujano ME, Preclinical evidence of the anxiolytic and sedative-like activities of Tagetes erecta L. reinforces its ethnobotanical approach. Biomed Pharmacother., 2017; 93: 383-390.

15. Plant Resources of Russia: Wild flowering plants, their composition and biological activity. MagnoliaceaeJuglandaceae, Ulmaceae, Moraceae, Cannabaceae, Urticaceae. Budantsev AL, St. Petersburg, Moscow, $1^{\text {st }}$ ed, KMK, 2008; 421, (available in Russian).

16. Seyed FN, Silvia T, William NS, Olga G, Antoni S, Nady B, Maria D, Azadeh M, Seyed MN, Chlorogenic Acid and Mental Diseases: From Chemistry to Medicine. Cur Neuropharmac., 2017; 15(4): 471-479.

17. Sviridov IV, Razuvaeva YaG, Shantanova LN, Antihypoxic properties of the dry extract from Serratula centauroides. Bulletin ESSC SB RAS, 2014; 6(100): 77-79, (available in Russian).

18. Sviridov IV, Razuvaeva YaG, Shantanova LN, Influence of dry extract Serratula centauroides L. on the functional status of central nervous system. Bull Buryat State Univ., 2015; 12: 184-188, (available in Russian).

19. Sviridov IV, Razuvaeva YaG, Shantanova LN, Nootropic and anticonvulsant properties of the dry extract from Serratula Centauroides. Bulletin ESSC $S B R A S$, 2015; 2(102): 89-92, (available in Russian).

20. Tsuji M, Miyagawa $\mathrm{K}$, Takeuchi $\mathrm{T}$, Takeda $\mathrm{H}$, Pharmacological characterization and mechanisms of the novel antidepressive- and/or anxiolytic-like substances identified from Perillae Herba. Jpn J Pharmacol., 2008; 28(4): 159-167.

21. Tsybiktarova LP, Nikolaeva IG, Nikolaeva GG, Determination of vitamins B complex in Serratula centauroides L. World J Pharmaceut Res., 2016; 5(4): 261-265.

22. Tsybiktarova LP, Taraskin VV, Nikolaeva IG, Radnaeva LD, Nikolaeva GG, Garmaeva LL, Lipids from Serratula centauroides L. Chem Natur Comp., 2016; 52(2): 294-295.

23. Tsybiktarova LP, Taraskin VV, Nikolaeva IG, Radnaeva LD, Gereltu B, Nikolaeva GG, Constituent Composition of Essential Oil from Serratula centauroides. Chem Natur Comp., 2016; 52(6): 1123-1124.

24. Vignes M, Maurice T, Lanté F, Nedjar M, Thethi K, Guiramand J, Récasens M, Anxiolytic properties of green tea polyphenol (-)-epigallocatechin gallate (EGCG). Brain Res., 2006; 1110(1): 102-115.

25. Volodin VV, Phytoecdysteroids. Nauka, St. Petersburg, 2003; 293, (available in Russian).

26. Vorob'eva AN, Rybin VG, Zarembo EV, Boltenkov EV, Phytoecdysteroids from Serratula centauroides. Chem Natur Comp., 2005; 1: 105-106.

27. Vorob'eva AN, Zarembo EV, Rybin VG, Far Eastern species of Stemmacantha Cass and Serratula L. genus - perspective sources phytoecdysteroids (review). 
FARMACIA, 2019, Vol. 67, 3

Bull Physiol Pathol Respir., 2006; 22: 90-93, (available in Russian).

28. Voronina TA, Seredenin SB, Methodical recommendations on the study of tranquilizing (anxiolytic) effect of pharmacological substances. Guidebook on experimental (preclinical) study of new pharmacological substances. Moscow, 2012; 253-263, (available in Russian).
29. Wang H, Wang H, Cheng H, Che Z, Ameliorating effect of luteolin on memory impairment in an Alzheimer's disease model. Mol Med Rep., 2016; 13(5): 4215-4220.

30. Wang X, Chen Y, Wang Q, Sun L, Li G, Zhang Ch, Huang J, Chen L, Zhai H, Support for Natural SmallMolecule Phenols as Anxiolytics. Molecules, 2017; 22(12): 2138: 1-11. 